\title{
Viabilitas Benih Koro (Canavalia ensiformis (L.) DC.) yang Disimpan pada Beberapa Jenis Kemasan dan Periode Simpan
}

Viability of Jack bean seed (Canavalia ensiformis $($ L.)DC.) storaged in various types of packaging materials and storage period

\author{
Furi Febriyanti dan Memen Surahman* \\ ${ }^{1}$ Departemen Agronomi Dan Hortikultura, Fakultas Pertanian, Institut Pertanian Bogor \\ (Bogor Agricultural University), Jl. Meranti, Kampus IPB Dramaga, Bogor 16680, Indonesia. \\ Telp.\&Faks.62-251-8629353 e-mail agronipb@indo.net.id \\ Penulis untuk korespondensi: memensurahman@yahoo.com
}

Disetujui 7 Januari 2015 / Published Online : 15 Januari 2015

\begin{abstract}
Jack bean belongs to the family of Leguminoceae and known as substitution plant for soybean because it has similar seed chemical composition with each other. The protein content in the seed caused legume has low seed storability. The objectives of this research is to study the effect of packaging material and storage period on different room storage condition to viability of jack bean seed (Canavalia ensiformis (L.) DC.). This research used nested design with two factors. The first factor is packaging material and the second factor is storage period. Jack bean was packaged with four kinds of package (polyethylen plastic, flour sack, plastic sack, and bottle glass) and period of storage up to six months in the AC and room storage condition. The results showed that polyethylen plastic and bottles glass was the best package for the jack bean seed storage during six months. Seed viability in both packaging was higher than flour sack and plastic sack for both room storage condition. This results showed that jack been seed could be stored in the AC and room temperature storage condition more than six months.
\end{abstract}

Keywords: leguminoceae, seed, storage, viability

\section{ABSTRAK}

Koro pedang putih termasuk famili Leguminoceae dan dikenal sebagai tanaman substitusi kedelai karena mempunyai kemiripan komposisi kimia benih. Kandungan protein dalam benih menyebabkan benih tanaman legum seperti kedelai memiliki masa penyimpanan yang pendek. Penelitian ini bertujuan untuk mempelajari pengaruh jenis kemasan dan periode penyimpanan pada kondisi ruang simpan berbeda terhadap viabilitas benih koro pedang putih (Canavalia ensiformis (L.)DC.). Penelitian ini menggunakan rancangan petak tersarang dengan dua faktor. Faktor pertama yaitu jenis kemasan dan faktor kedua yaitu periode simpan benih. Koro dikemas dalam empat jenis kemasan (plastik polietilen, karung terigu, karung plastik dan botol kaca) dan disimpan selama enam bulan di ruang suhu kamar dan ruang ber-AC. Hasil penelitian menunjukkan kemasan plastik polietilen dan botol kaca merupakan kemasan yang paling baik untuk penyimpanan benih koro pedang putih selama enam bulan. Viabilitas benih koro pedang putih dalam kemasan tersebut lebih tinggi dibandingkan kemasan karung terigu dan karung plastik untuk kedua ruang penyimpanan. Hasil ini mengindikasikan bahwa benih koro dapat disimpan dalam ruang AC maupun kamar lebih dari enam bulan.

Kata kunci: benih, daya berkecambah, legum, penyimpanan 


\section{PENDAHULUAN}

Koro pedang putih (Canavalia ensiformis (L.) DC.) merupakan salah satu tanaman yang diharapkan dapat menjadi substitusi kedelai untuk bahan pangan seperti tahu dan tempe. Benih koro memiliki protein cukup tinggi sekitar 18-25\% dan karbohidrat 50-60 \% (van der Mesen dan Somaatmadja, 1993) sedangkan beberapa varietas kedelai dalam negeri mengandung protein 36.9 $45.6 \%$ dan kandungan lemak antara 13.0-19.6\% (Ginting dan Tastra, 2007). Pengetahuan masyarakat tentang koro pedang putih belum tersebar secara merata pada beberapa wilayah di Indonesia. Tanaman koro secara botani dapat tumbuh di berbagai kondisi lahan sehingga penanaman koro pedang ini cocok diterapkan di Indonesia (Puslitbangtan, 2007).

Produksi koro harus didukung oleh tersedianya benih bermutu untuk meningkatkan produktivitas. Mutu benih mencakup mutu genetik, fisik, fisiologis, dan patologis. Salah satu faktor yang mempengaruhi mutu benih yaitu kondisi penyimpanan sebelum benih didistribusikan kepada konsumen. Penyimpanan benih setelah panen yang termasuk upaya memperpanjang viabilitas benih perlu dikembangkan. Dengan demikian, ketersediaan benih dengan mutu yang tinggi lebih terjamin dan konsumen dapat memperoleh benih koro pedang setiap saat dengan harga yang terjangkau.

Viabilitas benih secara alami akan menurun seiring lamanya penyimpanan sehingga diperlukan kondisi ruang simpan dan jenis kemasan yang sesuai untuk mengurangi kecepatan kemunduran benih. Faktor-faktor yang mempengaruhi viabilitas benih selama penyimpanan yaitu faktor biotik (kondisi benih, serangga dan hama gudang, serta cendawan) dan faktor abiotik meliputi suhu, kelembaban, dan komposisi gas (Justice dan Bass, 2002). Faktor yang paling berpengaruh selama penyimpanan yaitu kadar air benih dan suhu ruang penyimpanan. Semakin tinggi kadar air benih dan suhu ruang simpan maka viabilitas benih akan menurun dengan cepat untuk benih ortodoks (termasuk koro pedang putih). Kadar air benih berkorelasi positif dengan kelembaban nisbi (RH) ruang simpan sehingga peningkatan RH akan meningkatkan kadar air benih. Suhu dan RH di ruang kamar tidak dapat dikendalikan sehingga pengemasan benih perlu dilakukan untuk mengurangi kecepatan kemunduran benih. Penelitian mengenai jenis kemasan dan periode simpan benih diperlukan untuk mempertahankan viabilitas benih koro. Penelitian ini diharapkan dapat memberikan informasi daya simpan benih koro.

Penelitian ini bertujuan mempelajari pengaruh jenis kemasan dan periode penyimpanan pada kondisi ruang simpan berbeda terhadap viabilitas benih koro pedang putih (Canavalia ensiformis (L.) DC.).

\section{BAHAN DAN METODE}

Penelitian ini dilaksanakan pada bulan Oktober 2012 sampai dengan April 2013 di Laboratorium Ilmu dan Teknologi Benih, Gudang Penyimpanan Departemen Agronomi dan Hortikultura, dan Rumah Plastik K.P Leuwikopo IPB, Dramaga, Bogor. Bahan yang digunakan dalam penelitian ini adalah benih koro pedang putih yang telah dipanen pada bulan September 2012. Jenis kemasan yang digunakan adalah kemasan plastik polietilen, karung terigu, karung plastik, dan botol kaca. Alat-alat yang digunakan meliputi peralatan laboratorium untuk mengukur kadar air serta pengukur suhu dan RH (hygrothermometer).

Penelitian ini terdiri atas dua percobaan. Percobaan pertama adalah percobaan pada ruang suhu ber-AC dan percobaan kedua adalah penyimpanan pada suhu ruang kamar. Percobaan ini menggunakan rancangan percobaan petak tersarang (nested design). Faktor pertama adalah jenis kemasan yang terdiri atas empat taraf yaitu plastik polietilen, karung terigu, karung plastik, dan botol kaca. Faktor kedua adalah periode simpan yaitu 2, 4, dan 6 bulan. Benih diukur kadar airnya terlebih dahulu kemudian dikemas menggunakan jenis kemasan sesuai perlakuan. Benih yang sudah dikemas dimasukkan ke dalam dua tempat penyimpanan yaitu ruang ber-AC dan ruang suhu kamar. Penyimpanan dilakukan selama enam bulan dan pengujian viabilitas benih dilakukan setiap dua bulan selama periode penyimpanan. Pengujian viabilitas benih menggunakan media pasir di rumah plastik. Tolak ukur yang diamati yaitu kadar air (KA), daya berkecambah (DB), kecepatan tumbuh $\left(\mathrm{K}_{\mathrm{CT}}\right)$, indeks vigor (IV), keserampakan tumbuh $\left(\mathrm{K}_{\mathrm{ST}}\right)$, potensi tumbuh maksimum (PTM), dan berat kering kecambah normal (BKKN). Setiap percobaan dilakukan tiga ulangan. Data yang diperoleh dianalisis menggunakan software SAS 9.1. Uji $\mathrm{F}$ dilakukan untuk mengetahui pengaruh perlakuan. Hasil uji $F$ yang menunjukkan berpengaruh nyata pada taraf alfa $5 \%$, dilakukan uji DMRT (Duncan Multiple Range Test). Selain itu, dilakukan uji-t untuk mengetahui perbedaan antar ruang penyimpanan benih. 
Bul. Agrohorti 3 (1) : 119 - 126 (2015)

\section{HASIL DAN PEMBAHASAN}

\section{Penyimpanan Benih Koro Pedang Putih di Ruang} AC

Viabilitas awal berperan besar jika benih mengalami periode simpan panjang dalam kondisi tidak ideal (Ilyas, 1986). Kondisi awal benih koro sebelum perlakuan yaitu memiliki kadar air $13.55 \%$ dan daya berkecambah $65 \%$. Pengaruh perlakuan kemasan dan periode penyimpanan terhadap kadar air dan viabilitas benih koro akan terlihat selama periode penyimpanan enam bulan. Viabilitas awal benih koro pedang putih yang digunakan untuk penelitian ini disajikan pada Tabel 1.

Tabel 1. Kadar air dan viabilitas awal benih koro pedang putih sebelum perlakuan

\begin{tabular}{ll}
\hline Peubah & Nilai \\
\hline Kadar air (KA) & $13.55 \%$ \\
Potensi tumbuh maksimum (PTM) & $69 \%$ \\
Daya berkecambah (DB) & $65 \%$ \\
Berat kering kecambah normal (BKKN) & $5.47 \mathrm{~g}$ \\
Indeks vigor (IV) & $54 \%$ \\
Kecepatan tumbuh $\left(\mathrm{K}_{\mathrm{CT}}\right)$ & $11.25 \%$ etmal $^{-1}$ \\
Keserempakan tumbuh $\left(\mathrm{K}_{\mathrm{ST}}\right)$ & $54 \%$ \\
\hline
\end{tabular}

Interaksi antara kedua faktor
diperlukan untuk mengetahui hubungan jenis kemasan dan periode penyimpanan selama enam bulan. Interaksi yang terjadi antara kedua faktor berpengaruh nyata terhadap kadar air dan tolok ukur viabilitas potensial yaitu peubah DB dan PTM (Tabel 2). Interaksi antar kedua faktor berpengaruh nyata terhadap peubah KA, DB, dan PTM. Peubah KA, DB dan PTM mengalami fluktuasi dari bulan ke-2 hingga bulan ke-6.

Tabel 2. Pengaruh interaksi jenis kemasan dan periode simpan terhadap kadar air dan viabilitas potensial benih koro pedang putih di ruang $\mathrm{AC}$

\begin{tabular}{lccc}
\hline & \multicolumn{3}{c}{ Periode simpan (bulan) } \\
\cline { 2 - 4 } Jenis kemasan & 2 & 4 & 6 \\
\hline & ----------------- \\
Plastik polietilen & $7.82 \mathrm{~d}$ & KA $(\%)$ & $10.80 \mathrm{c}$ \\
Karung terigu & $7.55 \mathrm{~d}$ & $9.87 \mathrm{c}$ & $8.10 \mathrm{~d}$ \\
Karung plastik & $7.48 \mathrm{~d}$ & $15.74 \mathrm{a}$ & $8.03 \mathrm{~d}$ \\
Botol kaca & $6.98 \mathrm{~d}$ & $16.89 \mathrm{a}$ & $10.85 \mathrm{c}$ \\
& ---------- & $10.43 \mathrm{c}$ & ----------- \\
Plastik polietilen & $97.00 \mathrm{ab}$ & PTM $(\%)$ & $99.00 \mathrm{a}$ \\
Karung terigu & $91.00 \mathrm{abc}$ & $90.00 \mathrm{abc}$ & $95.00 \mathrm{ab}$ \\
Karung plastik & $91.00 \mathrm{abc}$ & $75.00 \mathrm{de}$ & $95.00 \mathrm{ab}$ \\
Botol kaca & $88.00 \mathrm{abcd}$ & $78.00 \mathrm{de}$ & $94.00 \mathrm{ab}$ \\
& ---------- & $83.00 \mathrm{bcd}$ & ---------- \\
Plastik polietilen & $75.00 \mathrm{abc}$ & DB $(\%)$ & $86.00 \mathrm{a}$ \\
Karung terigu & $66.00 \mathrm{bc}$ & $59.00 \mathrm{c}$ & $75.00 \mathrm{abc}$ \\
Karung plastik & $61.00 \mathrm{bc}$ & $26.00 \mathrm{~d}$ & $81.00 \mathrm{abc}$ \\
Botol kaca & $66.00 \mathrm{bc}$ & $16.00 \mathrm{de}$ & $83.00 \mathrm{ab}$ \\
\hline
\end{tabular}

a angka yang diikuti oleh huruf yang sama pada kolom dan baris yang sama menunjukkan tidak berbeda nyata dengan uji DMRT pada taraf alfa $5 \%$

Kadar air benih sebelum perlakuan memiliki nilai sebesar $13.55 \%$ dan selama penyimpanan enam bulan mengalami fluktuasi. Kadar air benih pada kemasan plastik polietilen dan botol kaca meningkat hingga bulan ke-6 sedangkan pada kemasan karung terigu dan karung plastik meningkat pada bulan ke-4 dan menurun pada bulan ke-6. Namun, kadar air benih pada bulan ke-6 untuk semua jenis kemasan masih berada di bawah batas aman kadar air untuk penyimpanan benih ortodoks yaitu $12 \%$. Persentase DB dan PTM pada semua jenis kemasan menurun pada bulan ke-4 dan meningkat pada bulan ke-6. Fluktuasi kadar 
air benih terjadi pada kemasan karung terigu dan karung plastik karena kemasan bersifat porous sehingga mudah terjadi pertukaran air dan udara dari lingkungan penyimpanan. Kadar air benih dipengaruhi oleh kelembaban relatif (RH) ruang simpan. Kelembaban relatif menyatakan uap air yang terkandung dalam udara di ruang simpan. Uap air akan meningkatkan kadar air benih apabila disimpan dalam kemasan porous. Hal ini sesuai dengan hasil penelitian Hutahaean (2008) bahwa benih kedelai varietas Kaba yang disimpan dalam kemasan kantong terigu mengalami kemunduran yang lebih cepat dibandingkan benih dalam kemasan kaleng dan plastik. Interaksi antar kedua faktor berpengaruh nyata terhadap peubah KA, DB, dan PTM. Peubah
KA, DB dan PTM mengalami fluktuasi dari bulan ke-2 hingga bulan ke-6. Kadar air benih sebelum perlakuan memiliki nilai sebesar $13.55 \%$ dan selama penyimpanan enam bulan mengalami fluktuasi. Kadar air benih pada kemasan plastik polietilen dan botol kaca meningkat hingga bulan ke-6 sedangkan pada kemasan karung terigu dan karung plastik meningkat pada bulan ke-4 dan menurun pada bulan ke-6. Namun, kadar air benih pada bulan ke-6 untuk semua jenis kemasan masih berada di bawah batas aman kadar air untuk penyimpanan benih ortodoks yaitu $12 \%$. Persentase DB dan PTM pada semua jenis kemasan menurun pada bulan ke-4 dan meningkat pada bulan ke-6.

Tabel 3. Pengaruh interaksi jenis kemasan dan periode simpan terhadap vigor benih koro pedang putih di ruang AC

\begin{tabular}{lccc}
\hline \multirow{2}{*}{ Jenis kemasan } & \multicolumn{3}{c}{ Periode simpan (bulan) } \\
\cline { 2 - 4 } & 2 & 4 & 6 \\
\hline & ------------- \\
Plastik polietilen & $6.27 \mathrm{~b}$ & BKKN $(\mathrm{g})$ & $8.70 \mathrm{ab}$ \\
Karung terigu & $8.13 \mathrm{ab}$ & $6.81 \mathrm{ab}$ & $7.03 \mathrm{ab}$ \\
Karung plastik & $7.00 \mathrm{ab}$ & $3.05 \mathrm{c}$ & $8.40 \mathrm{ab}$ \\
Botol kaca & $7.52 \mathrm{ab}$ & $2.62 \mathrm{c}$ & $9.86 \mathrm{a}$ \\
& ---------- & $0.66 \mathrm{~d}$ & --------- \\
Plastik polietilen & $33.00 \mathrm{ab}$ & $\mathrm{IV}(\%)$ & $44.00 \mathrm{ab}$ \\
Karung terigu & $27.00 \mathrm{bc}$ & $3.00 \mathrm{c}$ & $36.00 \mathrm{ab}$ \\
Karung plastik & $34.00 \mathrm{ab}$ & $1.00 \mathrm{c}$ & $56.00 \mathrm{a}$ \\
Botol kaca & $42.00 \mathrm{ab}$ & $2.00 \mathrm{c}$ & $40.00 \mathrm{ab}$ \\
& -------------- \\
Plastik polietilen & $13.27 \mathrm{a}$ & $3.00 \mathrm{c}$ & $14.90 \mathrm{a}$ \\
Karung terigu & $11.59 \mathrm{a}$ & $\mathrm{K}_{\mathrm{CT}}(\%$ etmal & $13.27 \mathrm{a}$ \\
Karung plastik & $10.99 \mathrm{a}$ & $9.60 \mathrm{a}$ & $14.96 \mathrm{a}$ \\
Botol kaca & $12.09 \mathrm{a}$ & $4.01 \mathrm{bc}$ & $13.74 \mathrm{a}$ \\
& ---------- & $2.59 \mathrm{c}$ & --------- \\
Plastik polietilen & $61.00 \mathrm{a}$ & $0.95 \mathrm{c}$ & $66.00 \mathrm{a}$ \\
Karung terigu & $53.00 \mathrm{ab}$ & $\mathrm{K}_{\mathrm{ST}}(\mathrm{g})$ & $57.00 \mathrm{ab}$ \\
Karung plastik & $48.00 \mathrm{ab}$ & $35.00 \mathrm{~b}$ & $64.00 \mathrm{a}$ \\
Botol kaca & $53.00 \mathrm{ab}$ & $11.00 \mathrm{c}$ & $59.00 \mathrm{a}$ \\
\hline
\end{tabular}

a angka yang diikuti oleh huruf yang sama pada kolom dan baris yang sama menunjukkan tidak berbeda nyata dengan uji DMRT pada taraf alfa $5 \%$

Tabel 3 menunjukkan interaksi jenis kemasan dan periode simpan terhadap vigor benih koro. Peubah berat kering kecambah normal (BKKN), indeks vigor (IV), kecepatan tumbuh $\left(\mathrm{K}_{\mathrm{CT}}\right)$, dan keserampakan tumbuh $\left(\mathrm{K}_{\mathrm{ST}}\right)$ merupakan tolak ukur vigor benih. Peningkatan kadar air pada bulan ke-4 turut mempengaruhi vigor benih koro pedang putih. Nilai BKKN pada kemasan plastik polietilen meningkat setiap bulannya sedangkan pada kemasan karung terigu, karung plastik dan botol kaca menurun pada bulan ke-4 dan meningkat pada bulan ke-6. Nilai peubah IV, $\mathrm{K}_{\mathrm{CT}}$ dan $\mathrm{K}_{\mathrm{ST}}$ menurun dari bulan ke-2 ke bulan ke-4 dan meningkat dari bulan ke-4 ke bulan ke-6.

Pengujian viabilitas dan vigor benih dilakukan di rumah plastik menggunakan media pasir. Nilai IV benih koro pada Tabel 3 rendah selama masa pengujian vigor benih. Rendahnya nilai IV diduga karena perkecambahan benih koro berjalan lambat. Adanya perbedaan suhu yang drastis secara cepat dari suhu ruang $\mathrm{AC}$ ke 
suhu rumah plastik saat pengujian viabilitas dan vigor diduga dapat membuat benih mengalami kondisi suboptimum selama perkecambahan.

\section{Penyimpanan Benih Koro di Ruang Suhu Kamar}

Ruang kamar memiliki fluktuasi suhu dan RH yang nyata dibandingkan ruang AC. Jenis kemasan dan periode simpan akan lebih berpengaruh terhadap penyimpanan benih di ruang kamar. Interaksi jenis kemasan dan periode simpan (Tabel 6) berpengaruh nyata terhadap peubah KA dan DB. Kadar air benih pada kemasan plastik polietilen meningkat setiap bulannya sedangkan pada kemasan botol kaca meningkat pada bulan ke-4 dan menurun pada bulan ke-6. Kadar air benih koro pada kemasan karung terigu dan karung plastik kadar air benih menurun pada bulan ke-4 dan meningkat pada bulan ke-6.

Kadar air benih berkesetimbangan dengan kelembapan relatif udara lingkungan simpan sehingga peningkatan kelembapan relatif udara di ruang kamar akan mengakibatkan terjadinya peningkatan kadar air benih. Selain itu, koro memiliki kandungan protein sehingga menurut Kusumawana (1988), benih yang mengandung protein tinggi sangat higroskopis dan benih yang mengandung karbohidrat lebih mudah menyerap air daripada benih yang mengandung lemak. Benih yang mengandung protein mampu menyerap dan menahan kadar air sehingga memungkinkan terjadinya peningkatan kadar air benih.

Tabel 4. Pengaruh interaksi jenis kemasan dan periode simpan terhadap kadar air dan viabilitas benih koro pedang putih di ruang kamar

\begin{tabular}{lccc}
\hline & \multicolumn{3}{c}{ Periode simpan (bulan) } \\
\cline { 2 - 4 } Jenis kemasan & 2 & 4 & 6 \\
\hline & ------------- \\
Plastik polietilen & $9.21 \mathrm{f}$ & KA $(\%)$ & $11.56 \mathrm{c}$ \\
Karung terigu & $14.20 \mathrm{ab}$ & $10.99 \mathrm{~cd}$ & $14.61 \mathrm{a}$ \\
Karung plastik & $13.59 \mathrm{~b}$ & $7.83 \mathrm{~g}$ & $14.87 \mathrm{a}$ \\
Botol kaca & $7.94 \mathrm{~g}$ & $7.70 \mathrm{~g}$ & $9.95 \mathrm{e}$ \\
& --------- & $10.72 \mathrm{~d}$ & ---------- \\
Plastik polietilen & $93.33 \mathrm{bcd}$ & PTM $(\%)$ & $100.00 \mathrm{a}$ \\
Karung terigu & $92.00 \mathrm{~cd}$ & $94.67 \mathrm{ab}$ \\
Karung plastik & $100.00 \mathrm{a}$ & $93.00 \mathrm{bcd}$ & $100.00 \mathrm{a}$ \\
Botol kaca & $100.00 \mathrm{a}$ & $96.00 \mathrm{abc}$ & $100.00 \mathrm{a}$ \\
& $92.00 \mathrm{~cd}$ & $96.00 \mathrm{abc}$ & ----------- \\
Plastik polietilen & ---------- & DB $(\%)$ & $97.33 \mathrm{a}$ \\
Karung terigu & $82.67 \mathrm{bc}$ & $42.67 \mathrm{~d}$ & $65.33 \mathrm{c}$ \\
Karung plastik & $82.67 \mathrm{abc}$ & $8.00 \mathrm{e}$ & $92.00 \mathrm{abc}$ \\
Botol kaca & $88.00 \mathrm{bc}$ & $40.00 \mathrm{~d}$ & $98.00 \mathrm{abc}$
\end{tabular}

${ }^{a}$ angka yang diikuti oleh huruf yang sama pada kolom dan baris yang sama menunjukkan tidak berbeda nyata dengan uji DMRT pada taraf alfa $5 \%$

Pengujian vigor benih koro diperlukan untuk melihat kemampuan tumbuh di lapangan. Hasil interaksi antara kedua faktor berpengaruh nyata terhadap peubah BKKN, IV, $\mathrm{K}_{\mathrm{CT}}$ dan $\mathrm{K}_{\mathrm{ST}}$. Nilai semua peubah menurun dari bulan ke-2 ke bulan ke-4 dan meningkat dari bulan ke-4 ke bulan ke-6 (Tabel 5). Peubah BKKN menunjukkan kemasan plastik polietilen, karung plastik dan botol kaca berbeda nyata dari bulan ke-2 dengan bulan ke-4 dan tidak berbeda nyata pada bulan ke-2 dengan bulan ke-6. Nilai IV pada kemasan karung plastik berbeda nyata pada bulan ke-2 ke bulan ke-4 namun tidak berbeda nyata pada bulan ke- 2 dan bulan ke-6. Peubah $\mathrm{K}_{\mathrm{CT}}$ berbeda nyata dari bulan ke-2 ke bulan ke-4 namun tidak berbeda nyata dari bulan ke-2 dan bulan ke-6. Peubah KST berbeda nyata pada bulan ke-2 dan bulan ke-4 namun tidak berbeda nyata pada bulan ke2 dan bulan ke-6. 
Bul. Agrohorti 3 (1) : 119 - 126 (2015)

Tabel 5. Pengaruh interaksi jenis kemasan dan periode simpan terhadap vigor benih koro di ruang kamar

\begin{tabular}{|c|c|c|c|}
\hline \multirow[b]{2}{*}{ Jenis kemasan } & \multicolumn{3}{|c|}{ Periode simpan (bulan) } \\
\hline & 2 & 4 & 6 \\
\hline & ------------ & $\mathrm{BKKN}(\mathrm{g})$ & ------------ \\
\hline Plastik polietilen & $8.96 b c$ & $4.33 \mathrm{~cd}$ & $11.32 \mathrm{ab}$ \\
\hline Karung terigu & $14.64 \mathrm{a}$ & $0.88 \mathrm{~d}$ & $6.23 \mathrm{bc}$ \\
\hline Karung plastik & $9.15 b c$ & $4.25 \mathrm{~cd}$ & $8.95 b c$ \\
\hline \multirow[t]{2}{*}{ Botol kaca } & $8.86 b c$ & $4.42 \mathrm{~cd}$ & $11.29 \mathrm{ab}$ \\
\hline & ------------ & IV $(\%)$ & ------------ \\
\hline Plastik polietilen & $49.33 \mathrm{~cd}$ & $16.00 \mathrm{~b}$ & $93.33 \mathrm{a}$ \\
\hline Karung terigu & $73.33 \mathrm{a}$ & $0.00 \mathrm{c}$ & $56.00 \mathrm{bcd}$ \\
\hline Karung plastik & $76.00 \mathrm{a}$ & $0.00 \mathrm{c}$ & $86.67 \mathrm{a}$ \\
\hline \multirow[t]{2}{*}{ Botol kaca } & $38.00 \mathrm{de}$ & $16.00 \mathrm{~b}$ & $92.00 \mathrm{a}$ \\
\hline & ----------- & $\mathrm{K}_{\mathrm{CT}}\left(\%\right.$ etmal $\left.^{-1}\right)$ & ------------ \\
\hline Plastik polietilen & $15.52 \mathrm{ab}$ & $7.49 \mathrm{c}$ & $18.93 \mathrm{a}$ \\
\hline Karung terigu & $17.96 \mathrm{ab}$ & $1.18 \mathrm{e}$ & $11.72 b$ \\
\hline Karung plastik & $16.13 \mathrm{ab}$ & $6.19 \mathrm{~cd}$ & $17.29 \mathrm{ab}$ \\
\hline \multirow[t]{2}{*}{ Botol kaca } & $13.93 \mathrm{ab}$ & $5.82 \mathrm{~d}$ & $18.59 \mathrm{ab}$ \\
\hline & & $\mathrm{K}_{\mathrm{ST}}(\%)$ & ------------ \\
\hline Plastik polietilen & $78.67 \mathrm{ab}$ & $28.00 \mathrm{cde}$ & $93.33 \mathrm{a}$ \\
\hline Karung terigu & $78.67 \mathrm{ab}$ & $1.33 \mathrm{e}$ & $56.00 \mathrm{bc}$ \\
\hline Karung plastik & $88.00 \mathrm{a}$ & $20.00 \mathrm{de}$ & $86.67 \mathrm{a}$ \\
\hline Botol kaca & $64.00 \mathrm{ab}$ & $30.00 \mathrm{~cd}$ & $92.00 \mathrm{a}$ \\
\hline
\end{tabular}

${ }^{a}$ angka yang diikuti oleh huruf yang sama pada kolom dan baris yang sama menunjukkan tidak berbeda nyata dengan uji DMRT pada taraf alfa $5 \%$

Perbandingan viabilitas dan kadar air benih koro pada suhu ruang AC dan kamar diperlukan untuk mengetahui kondisi ruang simpan yang lebih baik selama penyimpanan enam bulan. Hasil pada Tabel 6 menunjukkan perbandingan viabilitas dan kadar air benih koro saat penyimpanan enam bulan pada suhu ruang $\mathrm{AC}$ dan kamar berbeda nyata pada peubah PTM dan $\mathrm{K}_{\mathrm{ST}}$.

Tabel 6. Hasil uji-t kadar air dan viabilitas benih koro di ruang simpan AC dan kamar saat periode simpan enam bulan

\begin{tabular}{llrrc}
\hline No & Peubah & AC & Kamar & t-test \\
\hline 1 & & & & \\
2 & Kadar air (\%) & 9.45 & 12.75 & $0.0030^{\text {tn }}$ \\
3 & Potensi tumbuh maksimum (\%) & 98.75 & 95.75 & $0.0202^{*}$ \\
4 & Daya berkecambah (\%) & 86.75 & 79.00 & $0.1739^{\text {tn }}$ \\
5 & Berat kering kecambah normal (g) & 8.50 & 9.04 & $0.5460^{\text {tn }}$ \\
6 & Indeks vigor (\%) & 59.75 & 44.00 & $0.0680^{\text {tn }}$ \\
7 & Kecepatan tumbuh (\% etmal $\left.{ }^{-1}\right)$ & 16.30 & 14.22 & $0.0839^{\text {tn }}$ \\
\hline
\end{tabular}

*)berbeda nyata pada taraf alfa 5\% berdasarkan uji-t, tn=tidak berbeda nyata pada taraf alfa 5\% berdasarkan uji-t

Nilai PTM dan $\mathrm{K}_{\mathrm{ST}}$ benih koro di ruang AC lebih tinggi dibandingkan penyimpanan benih di ruang kamar. Peubah KA, DB, BKKN, IV dan $\mathrm{K}_{\mathrm{CT}}$ tidak berbeda nyata antar kedua ruang simpan. Hal ini mengindikasikan bahwa benih koro dapat disimpan dalam ruangan $\mathrm{AC}$ maupun kamar selama enam bulan namun vigor benih koro yang disimpan pada ruang AC lebih tinggi dibandingkan penyimpanan benih di ruang kamar. Nilai PTM benih setelah penyimpanan enam bulan masih memiliki persentase di atas $95 \%$. Potensi tumbuh maksimum menunjukkan kemampuan benih tumbuh pada keadaan optimum. Persentase PTM yang tinggi mengindikasikan bahwa benih koro yang memiliki ketebalan kulit sekitar $2 \mathrm{~mm}$ tidak termasuk benih keras karena ketebalan kulit tidak menghambat proses perkecambahan. Nilai $\mathrm{K}_{\mathrm{ST}}$ mengindikasikan vigor suatu lot benih. Lot benih yang kurang vigor akan tumbuh bervariasi. Benih yang memiliki vigor 
yang tinggi akan lebih serempak berkecambah, karena memiliki cadangan makanan yang tinggi, sehingga dapat membantu untuk berkecambah secara serempak di lingkungan yang optimum maupun yang suboptimum.

Benih yang dikemas dan disimpan pada ruang suhu rendah memiliki nilai kadar air rendah dan viabilitas yang lebih tinggi daripada benih yang disimpan pada ruang suhu tinggi. Penelitian Purwanti (2004) pada benih kedelai varietas Wilis dengan KA awal 9\% dan DB 100\% yang disimpan pada suhu rendah $\left(21-23{ }^{\circ} \mathrm{C}\right)$ menggunakan kemasan kaleng maupun kantong plastik ternyata masih mempunyai persentase DB lebih besar dari $80 \%$ setelah periode simpan enam bulan. Perlakuan kedelai pada suhu tinggi (27-29 ${ }^{\circ} \mathrm{C}$ ) membuat DB benih turun menjadi $60 \%$ pada bulan kedua dan $41 \%$ setelah periode simpan enam bulan. Penyimpanan benih koro sejalan dengan hasil penelitian kedelai tersebut. Penyimpanan benih koro pada suhu ruang AC lebih baik dibandingkan dengan penyimpanan benih pada suhu kamar. Hampir semua peubah viabilitas benih setelah penyimpanan enam bulan yang disimpan pada ruang ber-AC lebih tinggi dibandingkan benih yang disimpan pada ruang kamar. Nilai rataan kadar air benih pada bulan ke6 yang disimpan pada ruang ber-AC untuk semua jenis kemasan $9.45 \%$ sedangkan pada ruang kamar $12.75 \%$. Persentase DB yang disimpan pada ruang ber-AC sebesar $86.75 \%$ sedangkan pada ruang kamar $79 \%$.

Kadar air benih koro pada kemasan plastik polietilen dan botol kaca di suhu ruang simpan AC dan kamar mengalami peningkatan selama enam bulan seharusnya kemasan kedap mempunyai permeabilitas terhadap uap air yang rendah. Hal ini dapat disebabkan oleh beberapa faktor yaitu kualitas dan ketebalan kemasan plastik polietilen yang digunakan penelitian kurang baik sehingga memungkinkan terjadinya peningkatan kadar air. Peningkatan kadar air benih dalam kemasan botol kaca dapat disebabkan perekatan tutup botol yang kurang sempurna sehingga memungkinkan terjadi peningkatan kadar air. Benih yang disimpan pada kemasan kedap di ruang ber-AC seharusnya tidak mengalami peningkatan kadar air. Peningkatan kadar air benih dalam kemasan kedap di ruang ber-AC dapat disebabkan kondisi suhu di ruang ber-AC yang digunakan tidak jauh berbeda dengan suhu kamar. Suhu yang baik untuk penyimpanan benih di ruang AC yaitu di bawah $20^{\circ} \mathrm{C}$ sedangkan suhu ruang AC yang digunakan yaitu 20-23 ${ }^{\circ} \mathrm{C}$. Kisaran suhu ruang AC penyimpanan yang digunakan dapat menjadi faktor meningkatnya kadar air benih dalam kemasan kedap.
Sadjad et al. (1999) mendefinisikan daya simpan benih sebagai kemampuan lamanya benih disimpan. Benih secara alami akan mengalami kemunduran selama masa penyimpanan. Hasil penelitian Marwanto et al. (2003) menyatakan kandungan lignin pada kulit benih kedelai berpengaruh nyata terhadap kemunduran benih. Periode penyimpanan benih koro selama enam bulan menunjukkan hasil yang fluktuatif. Viabilitas benih meningkat pada bulan ke-2 lalu turun drastis di bulan ke-4 dan meningkat tajam di bulan ke-6 untuk semua kemasan dan kedua ruang penyimpanan. Salah satu tolok ukur yang mengalami fluktuatif yaitu daya berkecambah pada kemasan plastik di ruang AC. Daya berkecambah benih awal sebesar 65\% lalu meningkat menjadi $75 \%$ pada bulan ke-2. Daya berkecambah benih pada bulan ke-4 mengalami penurunan menjadi 59\% dan meningkat kembali menjadi $85 \%$ pada bulan ke-6. Hal ini dapat disebabkan karena terjadi peningkatan kadar air benih pada masa penyimpanan bulan ke-4. Peningkatan kadar air pada kemasan porous (karung plastik dan karung terigu) dapat terjadi karena kondisi lingkungan yang tidak terkontrol dan permeabilitas kemasan yang rendah. Peningkatan kadar air pada kemasan kedap (plastik polietilen dan botol kaca) selama periode penyimpanan dapat disebabkan benih yang disimpan selama enam bulan tetap melakukan aktivitas metabolisme yaitu respirasi meskipun dikemas dalam kemasan kedap. Respirasi benih menghasilkan gas karbon dioksida dan uap air. Gas karbon dioksida dan uap air dalam kemasan porous dapat keluar masuk kemasan sedangkan dalam kemasan kedap gas tersebut tidak dapat keluar kemasan dan terus berada dalam kemasan sehingga dapat meningkatkan kadar air benih.

\section{KESIMPULAN}

Jenis kemasan dan periode simpan mempengaruhi kadar air dan viabilitas benih selama penyimpanan di kedua ruang simpan. Interaksi antara kedua faktor berpengaruh nyata terhadap semua peubah pengamatan. Kadar air benih selama enam bulan pada semua kemasan mengalami fluktuasi. Kadar air benih pada bulan ke-6 dalam semua kemasan di kedua ruang simpan masih berada pada batas aman penyimpanan untuk benih ortodoks yaitu di bawah $12 \%$ kecuali kemasan karung terigu dan karung plastik memiliki kadar air di atas $12 \%$. Kemasan plastik polietilen dan botol kaca merupakan kemasan yang paling baik untuk penyimpanan benih koro pedang putih selama enam bulan karena menghasilkan viabilitas yang 
lebih tinggi dibandingkan kemasan karung terigu dan karung plastik untuk kedua ruang penyimpanan. Penyimpanan benih koro selama enam bulan di suhu ruang AC dan suhu ruang kamar menghasilkan viabilitas yang berbeda nyata hanya pada peubah PTM dan $\mathrm{K}_{\mathrm{ST}}$. Hal ini mengindikasikan bahwa koro dapat disimpan di suhu ruang AC dan kamar dengan periode simpan lebih dari enam bulan.

\section{DAFTAR PUSTAKA}

Ginting, E., Tastra, I.K. 2007. Standar mutu biji kedelai. Di dalam: Sumarno, Suyamto, Widjono A, Hermanto, Husni Kasim, editor. Kedelai - Teknik Produksi dan Pengembangan. Pusat Penelitian dan Pengembangan Tanaman Pangan. hlm 444 -463 .

Hutahaean. 2008. Viabilitas Benih Kedelai (Glycine $\max (\mathrm{L}$.$) Merr) dengan Varietas$ dan Kemasan yang Berbeda pada Beberapa Ruang Simpan [Tesis]. Medan (ID): Universitas Sumatera Utara.

Ilyas, S. 1986. Pengaruh Faktor Induced dan Enforced terhadap Vigor Benih Kedelai (Glycine max L. Merrill) dan Hubungannya dengan Produksi Per Hektar [Tesis]. Bogor (ID): Institut Pertanian Bogor.

Justice, O.E., dan Bass, L.N. 2002. Prinsip dan Praktek Penyimpanan Benih.Roesli R, penerjemah. Jakarta (ID): Raja Grafindo Persada. Terjemahan dari: Principles and Practises of Seed Storage.
Kusumawana, T. 1988. Pengaruh Kadar Air Awal dan Wadah Selama Periode Simpan terhadap Viabilitas Benih Pinus merkusii dalam Hubungannya dengan Konsumsi Oksigen [Skripsi]. Bogor (ID): Institut Pertanian Bogor.

Marwanto. 2003. Genotype differences in soybean seeds for resistance to field deterioration: II. The role of seed coat characteristics. JIPI (5):58-63.

[Puslitbangtan] Pusat Penelitian dan Pengembangan Tanaman Pangan.2007. Kelayakan dan teknologi budidaya koro pedang (Canavalia Sp.). Puslittan [internet]. [diunduh 2012 Desember 10]. Tersedia pada http:www.puslittan.bogor.net

Purwanti,S. 2004. Kajian suhu ruang simpan terhadap kualitas benih kedelai hitam dan kedelai kuning.JIPI(11):22-31.

Sadjad,S., Murniati, E., dan Ilyas, S. 1999. Parameter Pengujian Vigor Benih dari Komparatif ke Simulatif. Jakarta (ID): PT Gramedia Widiasarana Indonesia.

Van der Maesen dan Somaatmadja. 1993. Prosea sumber daya nabati asia tenggara I. Jakarta (ID) : Gramedia Pustaka Umum. 